\title{
Autoxidation and Toxicant-Induced Oxidation of Lipid and DNA in Monkey Liver: Reduction of Molecular Damage by Melatonin
}

\author{
Javier Cabrera ${ }^{1,2}$, Susanne Burkhardt ${ }^{1}$, Dun-Xian Tan ${ }^{1}$, Lucien C. Manchester ${ }^{1}$, Malgorzata Karbownik ${ }^{1}$ \\ and Russel J. Reiter ${ }^{1}$ \\ ${ }^{1}$ Department of Cellular and Structural Biology, The University of Texas Health Science Center at San Antonio, San \\ Antonio, TX 78229-3900, U.S.A., and ²Department of Pharmacology, Faculty of Medicine, University of Las \\ Palmas of Grand Canary, 35080 Las Palmas de Gran Canaria, Spain
}

(Received February 12, 2001; Accepted May 22, 2001)

\begin{abstract}
Melatonin, the main secretory product of the pineal gland, is a free radical scavenger and antioxidant which protects against oxidative damage due to a variety of toxicants. However, there is little information regarding melatonin's antioxidative capacity in tissues of primates. In this study we examined the protective effects of melatonin in monkey liver homogenates against lipid damage that occurred as a result of autoxidation or that induced by exogenous addition of $\mathrm{H}_{2} \mathrm{O}_{2}$ and ferrous iron $\left(\mathrm{Fe}^{2+}\right)$. Additionally, we tested melatonin's protective effect against oxidative damage to DNA induced by chromium(III) (CrIII) plus $\mathrm{H}_{2} \mathrm{O}_{2}$. The levels of malondialdehyde and 4-hydroxyalkenals were assayed as an index of lipid peroxidation, and the concentrations of 8-hydroxydeoxyguanosine (8-OHdG) as an endpoint of oxidative DNA damage. The increases in malondialdehyde+4-hydroxyalkenals concentrations as a consequence of autoxidation or after the addition of $\mathrm{H}_{2} \mathrm{O}_{2}$ plus $\mathrm{Fe}^{2+}$ to the homogenates were time-dependent. The accumulation of these damaged products due to either autoxidative processes or induced by $\mathrm{H}_{2} \mathrm{O}_{2}$ and $\mathrm{Fe}^{2+}$ were significantly reduced by melatonin in a concentration-dependent-manner. The levels of $8-\mathrm{OHdG}$ were elevated in purified monkey liver DNA incubated with a combination of $\mathrm{CrCl}_{3}$ plus $\mathrm{H}_{2} \mathrm{O}_{2}$. This rise in oxidatively damaged DNA was prevented by $10 \mu \mathrm{M}$ concentration of melatonin. Also, melatonin reduced the damage to DNA that was caused by autoxidative processes. These findings in monkey liver tissue document the ability of melatonin to protect against oxidative damage to both lipid and DNA in primate tissue, as observed previously in rodent tissue. The findings provide support for the use of melatonin as suitable agent to reduce damage inflicted by free radical species in primates.
\end{abstract}

Melatonin, 5-methoxy- $N$-acetyl-tryptamine, in mammals is synthesized primarily in the pineal gland and released into the blood with a circadian rhythm that peaks during the night (Reiter 1991). Melatonin possesses both hydrophilic and lipophilic characteristics (Costa et al. 1994; Shida et al. 1994) and easily penetrates all biological membranes to enter subcellular compartments. Melatonin participates in many physiological functions including the control of seasonal reproduction in animals (Goldman 1983), circadian rhythm regulation (Lewy et al. 1992) and possibly normal patterns of sleep (Haimov et al. 1995). It influences the growth of spontaneus and induced tumours in animals (Hill \& Blask 1998; Panzer \& Viljoen 1997) and may play a role in neuroimmunomodulation in rodents and man (Guerrero \& Reiter 1992; Maestroni 1993).

Melatonin also was reported to be a free radical scavenger and effective antioxidant (Tan et al. 1993a; Poeggeler et al. 1994; Reiter et al. 1997) and numerous reports have documented the protective actions of melatonin in various rodent models of oxidative stress (Reiter 2000; Reiter et al.

Author for correspondence: Russel J. Reiter, Department of Cellular and Structural Biology, Mail Code 7762, University of Texas Health Science Center, 7703 Floyd Curl Drive, San Antonio, TX 78229-3900, USA (fax +1 $210567 \quad 6948$, e-mail reiter@ uthscsa.edu).
2000). The indole is an efficient protector of nuclear (Tan et al. 1993b; Reiter 1999) and mitochondrial DNA (Reiter 1998), protein (Abe et al. 1994; Kim et al. 2000) and lipid (Pierrefiche et al. 1993; Melchiorri et al. 1994 \& 1995) against free radical attack.

Although there is extensive data regarding the antioxidant functions of melatonin in non-primate tissues, currently there is a dearth of information in terms of melatonin's ability to protect primate tissues from free radical damage. In this study we tested whether melatonin would suppress autoxidation and induced lipid peroxidation in hepatic homogenates and oxidative damage to purified liver DNA of monkey. Oxidative destruction of lipids was indicated by the quantity of malondialdehyde and 4-hydroxyalkenals in tissue homogenates; as an index of DNA damage, 8-hydroxydeoxyguanosine (8-OHdG) levels were estimated.

\section{Material and Methods}

Reagents. $\mathrm{CrCl}_{3} \cdot 6 \mathrm{H}_{2} \mathrm{O}, \mathrm{H}_{2} \mathrm{O}_{2}$ and ferrous sulfate were purchased from Sigma (St Louis, MO, USA). Pure melatonin was a gift from Helsinn Chemicals Co. (Biasca, Switzerland). RNase A and $\mathrm{T}_{1}$, proteinase $\mathrm{K}$, nuclease $\mathrm{P}_{1}$ and alkaline phosphatase were from Boehringer Mannheim (Indianapolis, IN, USA). A lipid peroxidation kit from Calbiochem (La Jolla, CA, USA) was used to measure the amount of thiobarbaturic acid reactive substances, malon- 


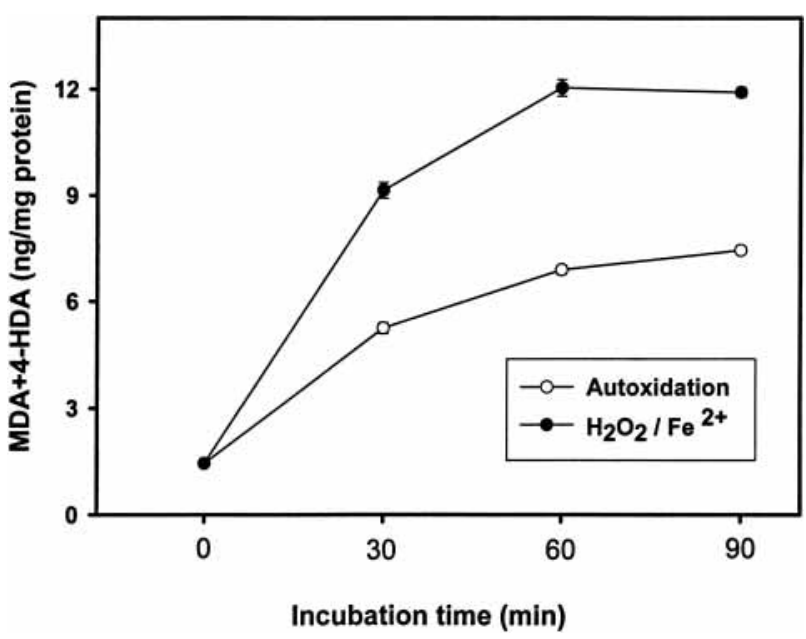

Fig. 1. Time course of autoxidation and induction of lipid peroxidation by $\mathrm{H}_{2} \mathrm{O}_{2}$ plus $\mathrm{FeSO}_{4}$ in monkey liver homogenates. Concentrations of $\mathrm{H}_{2} \mathrm{O}_{2}$ and $\mathrm{FeSO}_{4}$ were $100 \mu \mathrm{M}$ and $15 \mu \mathrm{M}$, respectively. Each mean is based on an $\mathrm{N}=4$.

dialdehyde+4-hydroxyalkenals. All others chemicals were of the highest quality available.

Animals. The liver of a healthy, young adult male green verrit monkey (Chlorocebus aethiops) (6 kg) was provided by Soho Primate Research Facilities, Basseterre, St. Kitts. The liver was dissected during a routine autopsy and immediately frozen at $-80^{\circ}$ until the studies were performed.

Assay for malondialdehyde and 4-hydroxyalkenals. A sample of 50 $\mathrm{mg}$ of liver was homogenized in $1 \mathrm{ml} 20 \mathrm{mM}$ iced cold Tris- $\mathrm{HCl}$ ( $\mathrm{pH}$ 7.4) buffer and the following treatments of homogenates were performed. Homogenates were incubated in a water bath at $37^{\circ}$ in the presence or absence of $100 \mu \mathrm{M} \mathrm{H}_{2} \mathrm{O}_{2}$ plus $15 \mu \mathrm{M} \mathrm{Fe}^{2+}$ for 0 , $30,60,90,120 \mathrm{~min}$. Another set of homogenates was incubated for $60 \mathrm{~min}$. at $37^{\circ}$ with different concentrations of melatonin. Additionally, a third set of hepatic homogenates was incubated at $37^{\circ}$ for 60 min. with $100 \mu \mathrm{M} \mathrm{H}_{2} \mathrm{O}_{2}$ plus $15 \mu \mathrm{M} \mathrm{Fe}^{2+}$ and increasing concentrations of melatonin.

After incubation, the reaction were terminated by placing the tubes on ice for $10 \mathrm{~min}$.; the homogenates were then centrifuged at $3000 \times \mathrm{g}$ for $10 \mathrm{~min}$. at $4^{\circ}$ and the malondialdehyde +4 -hydroxyalkenals levels were estimated in the supernatant as previously described (Melchiorri et al. 1994).

Protein concentration were measured by the Bradford (1976) method using bovine albumin as the standard.

$D N A$ isolation. DNA was isolated and purified as described previously (Shigenaga et al. 1994) with minor modifications. Liver tissue $(150 \mathrm{mg})$ was homogenized in $1 \mathrm{ml}$ ice cold buffer containing $0.1 \mathrm{M} \mathrm{NaCl}, 10 \mathrm{mM}$ EDTA, $10 \mathrm{mM}$ 2-mercaptoethanol and $0.5 \%$ Triton X-100 ( $\mathrm{pH} 8.0)$. The homogenates were centrifuged at $4^{\circ}$ for $10 \mathrm{~min}$. at $1,000 \times \mathrm{g}$. The supernatant was discarded and the crude pellet was resuspended in $0.5 \mathrm{ml}$ lysis solution $(120 \mathrm{mM} \mathrm{NaCl}, 10$ $\mathrm{mM}$ Tris, $1 \mathrm{mM}$ EDTA, $0.5 \%$ SDS, pH 8.0 ) with $20 \mu 15 \%$ butylated hydroxytoluene. RNA and protein were digested by incubating the samples with RNase and proteinase $\mathrm{K}$ for $1 \mathrm{hr}$ at $55^{\circ}$. After extraction, by mixing the samples with one volume each saturated phenol, 25:24:1 mixture of phenol/chloroform/isoamyl-alcohol and 24:1 mixture of chloroform/isoamyl alcohol, DNA was precipitated by the addition of two volumes of $-20^{\circ}$ ethanol. The purity of DNA, measured as the ratio $260 \mathrm{~nm} / 280 \mathrm{~nm}$ absorbances, was equivalent to standard commercial calf thymus DNA.
DNA treatment. Samples $(500 \mu \mathrm{g})$ of purified monkey liver DNA were dissolved in $10 \mathrm{mM}$ potassium phosphate buffer $(\mathrm{pH}$ 7.4) at a final volume of $0.45 \mathrm{ml}$; these were then incubated with $500 \mu \mathrm{M}$ $\mathrm{CrCl}_{3}$ and $0.5 \mathrm{mM} \mathrm{H}_{2} \mathrm{O}_{2}$ in the presence or absence of $10 \mu \mathrm{M}$ concentration of melatonin for $60 \mathrm{~min}$. at $37^{\circ}$ in a water bath. After incubation, $50 \mu \mathrm{l}$ sodium acetate (3M, pH 5.0) and two volumes of $-20^{\circ}$ ethanol was added to each sample, DNA was precipitated and washed once with $70 \%$ ethanol.

8-OHdG assay. The DNA was dried and dissolved in $200 \mu 1$ of 20 $\mathrm{mM}$ sodium acetate $\left(\mathrm{pH}\right.$ 5.0) denatured by heating at $95^{\circ}$ for 5 min., and then cooled on ice. The DNA samples were digested to nucleotides by incubation with 8 units of nuclease $\mathrm{P} 1$ at $37^{\circ}$ for 30 min. Then, $20 \mu \mathrm{l}$ of $1 \mathrm{M}$ Tris- $\mathrm{HCl}(\mathrm{pH} 8.0)$ were added and they were treated with four units of alkaline phosphatase at $37^{\circ}$ for 1 hr. The resulting deoxynucleoside mixture was filtered through a Millipore filter $(0.22 \mu \mathrm{m})$ and analysed by HPLC-ECD system. An ESA HPLC system equipped with eight channels CoulArray 5600 electrochemical detector was used: column, YMC-BD column (3 $\mu \mathrm{m}, 150 \times 4.6 \mathrm{~mm}$ i.d.); eluent, $5 \%$ aqueous methanol containing $12.5 \mathrm{mM}$ citric acid, $25 \mathrm{mM}$ sodium acetic acid, $30 \mathrm{mM}$ sodium hydroxide and $10 \mathrm{mM}$ acetic acid at a flow rate of $1 \mathrm{ml} / \mathrm{min}$. The quantities of 8-OHdG and 2-deoxyguanosine were measured using different channels and two oxidative potentials $(300 \mathrm{mV}, 900 \mathrm{mV}$, respectively). The level of $8-\mathrm{OHdG}$ in each sample was expressed as the ratio of 8 -OHdG to $10^{5} 2$-deoxyguanosine.

Statistical analysis. Statistical treatment of the data was performed using a one way analysis of variance (ANOVA) followed by StudentNewman-Keuls t-test. Values were accepted as being statistically different if a $\mathrm{P}$ value was $<0.05$.

\section{Results}

\section{Lipid peroxidation.}

The results show that liver homogenates of the green verrit monkey undergo autoxidation as indicated by the increased levels of lipid peroxidation products; this autoxidative response was time-dependent (fig. 1). Exposing liver homogenates to $\mathrm{H}_{2} \mathrm{O}_{2}$ plus $\mathrm{Fe}^{2+}$ also markedly induced lipid



Fig. 2. Suppressive effect of increasing concentrations of melatonin on products of lipid peroxidation (malondialdehyde plus 4-hydroxyalkenals, MDA+4-HDA) induced with $\mathrm{H}_{2} \mathrm{O}_{2}$ and $\mathrm{FeSO}_{4}$ in monkey liver homogenates. Incubation time was $60 \mathrm{~min}$. Values are means \pm S.E. $(\mathrm{n}=4)$. $* \mathrm{P}<0.05$ versus $\mathrm{H}_{2} \mathrm{O}_{2}$ plus $\mathrm{FeSO}_{4}$ alone. 


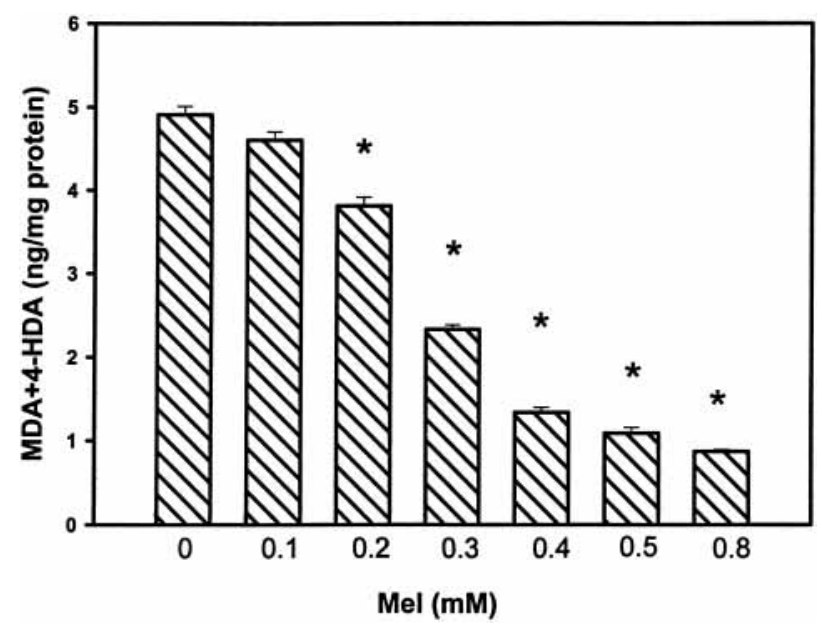

Fig. 3. Suppressive effect of melatonin on products of lipid peroxidation (malondialdehyde plus 4-hydroxyalkenals, MDA+4HDA) resulting from the autoxidation of monkey liver homogenates. The incubation time was $60 \mathrm{~min}$. Values are means \pm S.E. $(\mathrm{n}=4)$. ${ }^{*} \mathrm{P}<0.05$ versus control.

damage; likewise this damage exhibited a time-dependent relationship (fig. 1).

When the homogenates were co-incubated for $60 \mathrm{~min}$. with several concentrations of melatonin, the indole not only suppressed lipid peroxidation induced by exogenously added $\mathrm{H}_{2} \mathrm{O}_{2}$ plus $\mathrm{Fe}^{2+}$ (fig. 2), but also inhibited the accumulation of malondialdehyde +4-hydroxyalkenals resulting from autoxidation (fig. 3). In both cases the response to melatonin proceeded in a dose-dependent manner. The concentrations of melatonin required to suppress lipid peroxidation resulting from autoxidation or induced by exogenous oxidants in monkey liver were in the same dose range.

\section{DNA damage.}

When monkey liver DNA was incubated with $\mathrm{Cr}$ (III) (in the form of $\left.\mathrm{CrCl}_{3}\right)+\mathrm{H}_{2} \mathrm{O}_{2}$, the levels of 8-OHdG detected was approximately two times higher than those in the untreated controls. In the presence of $10 \mu \mathrm{M}$ melatonin, the $\mathrm{Cr}$ (III)-induced formation of 8-OHdG was completely inhibited (fig. 4).

\section{Discussion}

Free radicals are believed to be involved in numerous pathobiological processes such as inflammation (Grisham et al. 1984), heart attack and stroke (Globus et al. 1995; Janeiro 1995), pulmonary oxygen toxicity (Schaufstatter et al. 1984), neurodegenerative diseases (Yoshikawa 1993; Heyes 1996; Richardson \& Zhou 1996; Markesbury 1997), cancer (Ames \& Shigenaga 1993), radiation injury (Troll \& Wiesner 1985), aging (Harman 1991; Markesbury 1997; Reiter 1997) and the toxicity of many chemicals (Thomas \& Aust 1986; Cross et al. 1987). Additionally, the liver is a common target for free radical-induced damage. The sensitivity of the liver to these conditions is because it is a rich source of

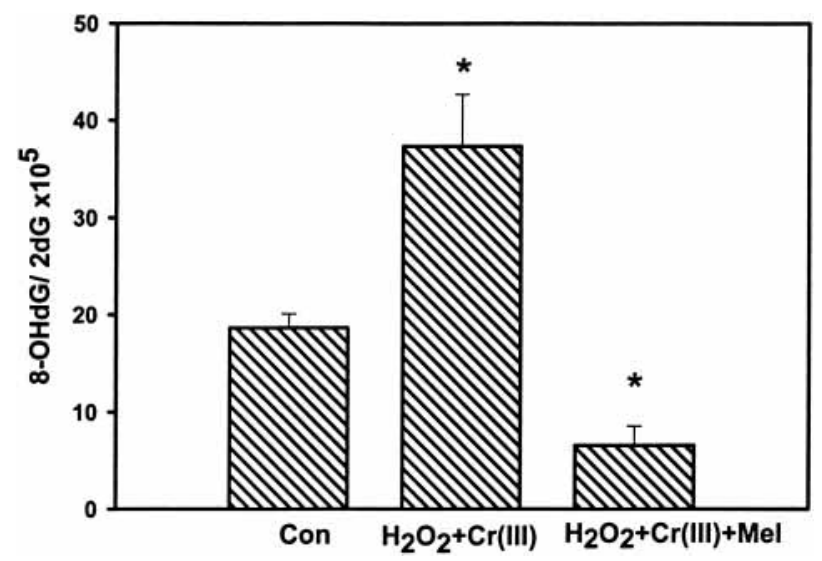

Fig. 4. Effect of melatonin $(10 \mu \mathrm{M})$ on Cr III $(500 \mu \mathrm{M})$ plus $\mathrm{H}_{2} \mathrm{O}_{2}$ $(0.5 \mathrm{mM})$-induced 8-hydroxy-2' deoxyguanosine (8-OHdG) levels in monkey liver DNA. The incubation time was $60 \mathrm{~min}$. Values are means \pm S.E. $(\mathrm{n}=4) * \mathrm{P}<0.05$ versus controls. In this study melatonin reduced the damaging effect of the reactants on DNA to levels below those of the controls.

microsomal enzymes which, by virtue of their classical phase I reactions, are crucial in activating many potential toxins to generate reactive species. Also, the anatomic relationship of the liver with the gastrointestinal track makes it the primary recipient of substances absorbed through the gut (Brent \& Rumack 1993a). An extremely diverse series of xenobiotics have been implicated as causes of free radicalinduced liver injury with some of the best-studied being carbon tetrachloride, halogenated aromatic hydrocarbons, ethanol, diquat, paraquat, acetaminophen, dioxins and adriamycin (Olson et al. 1981; Al-Bayati \& Stohs 1987; Brent \& Rumack 1993b). In every case where studies have been performed, melatonin reduces the oxidative toxicity of these xenobiotics, chemical toxins and processes (Brömme et al. 2000, Lopez-Gonzalez et al. 2000; Ohta et al. 2000, Granzotto et al. 2001; Okatani et al. 2001).

The role of melatonin in lowering free radical damage is well documented (Reiter et al. 1995, 1998a \& 1998b). Previous studies have shown that melatonin effectively protects lipids and DNA from oxidative damage in a variety of rodents models. In the current study we report, for the first time, the protection of melatonin against free radical mediated-injury in a primate tissue, the liver. The results clearly show that the levels of malondialdehyde+4-hydroxyalkenals in homogenates incubated at $37^{\circ}$ increased in a time-dependent manner, which indicates a strong tendency of monkey liver to undergo autoxidation. The breakdown of lipids in this situation is related to the oxygen concentration in the medium and the presence of endogenous oxidants.

When $\mathrm{H}_{2} \mathrm{O}_{2}$ and $\mathrm{Fe}^{2+}$ were added, levels of products of lipid peroxidation in the hepatic homogenates were significantly increased. This is known to be a consequence of ferrous iron donating an electron to $\mathrm{H}_{2} \mathrm{O}_{2}$ to form, via the Fenton reaction, the highly reactive hydroxyl radical $(\mathrm{OH})$. 
The $\mathrm{OH}$ readily damages lipids to initiate lipid peroxidation.

To examine whether melatonin has the capacity to protect primate liver against oxidative lipid damage, different concentrations of melatonin were added to the homogenates. The data obtained show that melatonin inhibits both autoxidation and the peroxidation of lipids induced by $\mathrm{H}_{2} \mathrm{O}_{2}$ plus $\mathrm{Fe}^{2+}$ in a dose-response manner. The concentrations of melatonin required to suppress the breakdown of lipids as a result of autoxidation or due to addition of $\mathrm{Fe}^{2+} / \mathrm{H}_{2} \mathrm{O}_{2}$ were in the same range $(0.2-0.8 \mathrm{mM})$.

$\mathrm{Cr}$ (III) plus $\mathrm{H}_{2} \mathrm{O}_{2}$ is capable of inducing oxidative DNA damage due to the fact that $\mathrm{Cr}$ (III) supports a Fenton-type reaction which generates the $\mathrm{OH}$. After its generation, this radical then targets DNA resulting in the accumulation of the oxidatively-damaged DNA base adduct 8-OHdG (Tsou et al. 1996; Lloyd et al. 1998); this is a key biomarker relevant to carcinogenesis, since the formation of $8-\mathrm{OHdG}$ in DNA causes misincorporation during replication and subsequently leads to $\mathrm{G} \rightarrow \mathrm{T}$ transversions (Shibutai et al. 1991; Cheng et al. 1992).

In the present study using homogenates derived from primate liver, melatonin was also shown to protect against oxidative DNA damage. When monkey liver DNA was incubated with $\mathrm{CrCl}_{3}+\mathrm{H}_{2} \mathrm{O}_{2}$ in absence of melatonin, the levels of $8-\mathrm{OHdG}$ detected were markedly increased. The addition of melatonin totally inhibited the formation of the oxidatively damaged product induced by $\mathrm{Cr}$ (III) plus $\mathrm{H}_{2} \mathrm{O}_{2}$. In fact, as shown in fig. 4, melatonin reduced $8-\mathrm{OHdG}$ levels below those measured in the control DNA. This means that the DNA, besides being damaged by toxin exposure, underwent autoxidation during incubation which was also inhibited by melatonin. The concentrations of $\mathrm{CrCl}_{3}$ plus $\mathrm{H}_{2} \mathrm{O}_{2}$ and melatonin selected for this study were based on previous work from this laboratory (data not shown). In those studies, which used tissues from several species, the optimal concentrations of $\mathrm{CrCl}_{3}$ plus $\mathrm{H}_{2} \mathrm{O}_{2}$ and melatonin were roughly $100 \mu \mathrm{M}$ and $10 \mu \mathrm{M}$, respectively. As a scavenger of reactive species, melatonin has been reported to detoxify the $\mathrm{OH}$, the peroxynitrite anion $\left(\mathrm{ONOO}^{-}\right)$and/or other reactive metabolites of oxygen including singlet oxygen $\left({ }^{1} \mathrm{O}_{2}\right)$ and hydrogen peroxide $\left(\mathrm{H}_{2} \mathrm{O}_{2}\right)$ (Tan et al. 1993a, b \& 2000; Reiter 2000; Reiter et al. 2000).

The protective effect of melatonin in the present study was likely attributable to its direct $\mathrm{OH}$ scavenging ability, and additionally to its ability to interact with its precursor, $\mathrm{H}_{2} \mathrm{O}_{2}$ (Tan et al. 2000). Additionally melatonin's protection could in part relate to its reported ability to bind metal ions (Limson et al. 1998). In this report melatonin was found to chelate aluminum, cadmiun, iron, copper and lead. Although the authors did not specifically investigate chromium, if melatonin does chelate the metals as indicated, it would also likely bind chromium and thereby reduce the formation of $\mathrm{OH}$ via the Fenton reaction.

Although it has been reported that physiological levels (as opposed to only pharmacological concentrations) of melatonin provide protection against oxidative damage in rodents (Tan et al. 1993b; Manev et al. 1996; Kilic et al. 1999), melatonin's importance as a physiologically-relevant direct free radical scavenger is still debated. The melatonin concentrations used in the current study were obviously in the pharmacological range. However, the homogenates were also incubated with oxidants in concentrations they would never experience in vivo. Thus, pharmacological concentrations of any antioxidant (including melatonin) would be required to reduce the resulting damage.

Considering that the antioxidant ability of any molecule in vivo may be different (depending on absorption, subcellular distribution, etc.) than in vitro, it is difficult to extrapolate our finding to the in vivo situation. However, melatonin's in vivo efficacy as a reliable free radical scavenger and antioxidant has been shown and numerous rodent studies have documented that melatonin protects membrane lipids, nuclear and mitochondria DNA and proteins from oxidative damage induced by a variety of free radical generating agents and processes in these species (Reiter et al. 1998a \& b).

Given these numerous reports, it seems likely that melatonin would function as an antioxidant in primates as well. Assuming that the primate liver more closely resembles the human liver than does that of rodents, it is surmised that melatonin would also protect the human liver from free radical damage.

\section{References}

Abe, M., R. J. Reiter, P. H. Orhii, M. Hara, B. Poeggeler \& L. R. Barlow-Walden: Inhibitory effect of melatonin on cataract formation in newborn rats: Evidence of an antioxidative role for melatonin. J. Pineal Res. 1994, 17, 94-100.

Al-Bayati, Z. A. F. \& S. J. Stohs: The role of iron in 2,3 ,7, 8-tetrachlorodibenzo-p-dioxin-induced lipid peroxidation by rat liver microsomes. Toxicol. Lett. 1987, 38, 115-121.

Ames, B. N. \& M.K . Shigenaga: Oxidants are major contributor to cancer and aging. In: DNA and free radicals. Eds.: B. Halliwell, O. I. Arouoma. Harwood, London, 1993, pp. 1-18.

Bradford, M.: A rapid and sensitive method for quantification of protein utilizing the principle of protein dye binding. Ann. Biochem. 1976, 71, 171-178.

Brent, J. A. \& B. H. Rumack: Role of free radicals in toxic hepatic injury I. Free radical biochemistry. Clin. Toxicol. 1993a, 31, 139171.

Brent, J. A. \& B. H. Rumack: Role of free radicals in toxic hepatic injury II. Are free radicals the cause of toxin-induced liver injury? Clini. Toxicol. 1993b, 31, 173-196.

Brömme, H. J., W. Mörke, E. Peschke, H. Ebelt \& D. Peschke: Scavenging effect of melatonin on hydroxyl radicals generated by alloxan. J. Pineal Res. 2000, 29, 201-209.

Cheng, K. C., D. S. Cahill, H. Kasai, S. Nishimura \& L. A. Loeb: 8-hydroxydeoxyguanosine, an abundant form of oxidative DNA damage, causes $\mathrm{G} \rightarrow \mathrm{T}$ and $\mathrm{A} \rightarrow \mathrm{C}$ substitutions. J. Biol. Chem. 1992, 267, 166-172.

Costa, E. J. X., R. H. Lopes \& M. T. Lamy-Freund: Permeability of pure lipid bilayers to melatonin. J. Pineal Res. 1994, 16, 123 124.

Cross, C. E., B. Haliwell, E. T. Borish, W. A. Pryor, B. N. Ames, R. L. Saul, J. M. McCord \& D. Harman: Oxygen radicals and human disease. Ann. Emerg. Med. 1987, 107, 526-545.

Globus, M. Y., R. Busto, B. Lin, H. Schnippering \& M. D. Ginsberg: Detection of free radical activity during transient glo- 
bal ischemia and recirculation: Effects of intra ischemic brain temperature modulation. J. Neurochem. 1995, 65, 1250-1256.

Goldman, B. O.: The physiology of melatonin in mammals. Pineal Res. Rev. 1983, 1, 145-182.

Granzotto, M., V. Rappozi, G. Decorti \& T. Giraldi: Effects of melatonin on doxorubicin cyctotoxicity in sensitive and pleiotropically resistant tumor cells. J. Pineal Res. 2001, in press.

Grisham, M. B., M. M. Jefferson \& E. L. Thomas: Role of monochloramine in the oxidation of erythrocyte hemoglobin by stimulated neutrophils. J. Biol. Chem. 1984, 259, 6766-6772.

Guerrero, J. M. \& R. J. Reiter: A brief survey of pineal glandimmune system interrelationships. Endocr. Res. 1992, 18, 91-113.

Haimov, I., P. Lavie, M. Laudon, P. Herer \& N. Zisapel: Melatonin replacement therapy of elderly insomniacs. Sleep 1995, 18, 598603.

Harman, D.: The aging process: Major risk factor for disease and death. Proc. Natl. Acad. Sci. U.S.A. 1991, 88, 5360-5363.

Heyes, M. P.: The kynurenine pathway and neurological disease and neurological disease. Therapeutic strategies. Adv. Exp. Med. Biol. 1996, 398, 125-129.

Hill, S. M. \& D. E. Blask: Effects of the pineal hormone melatonin on the proliferation and morphological characteristics of human breast cancer cells (MCF-7) in culture. Cancer Res. 1988, 48, 6121-6126.

Janeiro, D. R.: Ischemic heart disease and antioxidants: Mechanistic aspects of oxidative injury and its prevention. Crit. Rev. Food. Sci. Nutr. 1995, 35, 65-81.

Kim, S. J., R. J. Reiter, W. Qi, D. X. Tan \& J. Cabrera: Melatonin prevents oxidative damage to protein and lipid induced by ascorbate-Fe ${ }^{2+}$ - EDTA: Comparison with glutathione and $\alpha$-tocopherol. Neuroendocrinol. Lett. 2000, 21, 269-276.

Kilic, E., Y. G. Ozdemir, H. Bolay, H. Kelestimur, T. Dalkara: Pinealectomy aggravates and melatonin administration attenuates brain damage in focal ischemia. J. Cereb. Blood Flow Metab. 1999, 19, 511-516.

Lewy, A. J., S. Ahmed, J. M. Latham-Jackson \& R. L. Sack: Melatonin phase shift human circadian rhythm according to a phaseresponse curve. Chronobiol. Int. 1992, 9, 380-392.

Limson, J., T. Nyokong \& S. Daya: The interaction of melatonin and its precursors with aluminum cadmiun, copper, iron, lead and zinc: an adsorptive voltammetry study. J. Pineal Res. 1998, 24, 15-21.

Lloyd, D. R., P. L. Carmichael \& D. H. Phillips: Comparison of the formation of 8-hydroxy-2-deosyguanosione and single and double-strand breaks in DNA mediated by Fenton reaction. Chem. Res. Toxicol. 1998, 11, 420-427.

Lopez-Gonzalez, M. A., J. M. Guerrero, F. Rojas, F. Delgado: Ototoxicity caused by cisplatin is ameliorated by melatonin and other antioxidants. J. Pineal Res. 2000, 28, 73-80.

Maestroni, G. J. M.: The immunoendocrine role of melatonin. $J$. Pineal Res. 1993, 14, 1-10.

Manev, H., T. Uz, A. Kharlamov, J. Y. Joo: Increased brain damage after stroke or excitotoxic seizures in melatonin-deficient rats. FASEB J. 1996, 10, 1546-1551.

Markesbury, W. R.: Oxidative stress hypothesis of Alzheimer's disease. Free Radic. Biol. Med. 1997, 23: 134-137.

Melchiorri, D., R. J. Reiter, A. M. Attia, M. Hara, A. Burgos \& G. Nistico: Potent protective effect of melatonin on in vivo paraquatinduced damage in rats. Life Sci. 1994, 56, 83-89.

Melchiorri, D., R. J. Reiter, E. Sewerynek, L. D. Chen \& G. Nistico: Melatonin reduces kainite-induced lipid peroxidation in homogenates of different brain regions. FASEB J. 1995, 9, 1205-1210.

Ohta, Y., M. Kongo, E. Sasaki, K. Nishida \& I. Ishiguro: Therapeutic effect of melatonin on carbon tetrachloride-induced acute liver injury in rats. J. Pineal Res. 2000, 28, 119-126.

Okatani, Y., A. Wakatsuki, K. Shinohara, K. Taniguchi \& T. Fukaya: Melatonin protects against oxidative mitochondrial damage induced in rat placenta by ischemia and reperfusion. J. Pineal Res. 2001, in press.
Olson, R. D., R. C. Boerth, J. G. Gerber \& A. S. Nies: Mechanism of adriamycin cardiotoxicity: Evidence for oxidative stress. Life Sci. 1981, 29, 1393-1401.

Panzer, A. \& M. Viljoen: The validity of melatonin as an oncostatic agent. J. Pineal Res. 1997, 22, 184-202.

Pierrefiche, G., G. Topall, G. Courbain, I. Henriet \& H. Laborit: Antioxidant activity of melatonin in mice. Res. Commun. Chem. Pathol. Pharmacol. 1993, 80, 211-223.

Poeggeler, B., R. J. Reiter, R. Hardeland, E. Sewerynek, D. Melchiorri \& L. R. Barlow-Walden: Melatonin a highly potent endogenous radical scavenger and electron donor: new aspects of the oxidative chemistry of the indole accessed in vitro. Ann. NY Acad. Sci. 1994, 738, 419-420.

Reiter, R. J.: Pineal melatonin: Cell biology of its synthesis and of its physiological interactions. Endocrine Rev. 1991, 12, 151180.

Reiter, R. J.: Aging and oxygen toxicity: Relation to changes in melatonin. Age 1997, 20, 201-213.

Reiter, R. J.: Oxidative damage in the central nervous system: protection by melatonin. Prog. Neurobiol. 1998, 56, 339-384.

Reiter, R. J.: Oxidative damage to nuclear DNA: Amelioration by melatonin. Neuroendocrinol. Lett. 1999, 20, 145-150.

Reiter, R. J.: Melatonin: Lowering the high price of free radicals. News Physiol. Sci. 2000, 15, 246-250.

Reiter, R. J., D. Melchiorri, E. Sewerynek, B. Poeggeler, L. R. Barlow-Walden, J. I. Chuang, G. Ortiz \& D. Acuña Castroviejo: A review of the evidence supporting melatonin's role as an antioxidant. J. Pineal Res. 1995, 18, 1-11.

Reiter, R. J., L. Tang, J. J. Garcia \& A. Muñoz Hoyos: Pharmacological actions of melatonin in oxygen radical pathophysyology. Life Sci. 1997, 60, 2255-2271.

Reiter, R. J., J. M. Guerrero, J. J. Garcia \& D. Acuña Castroviejo. Reactive oxygen intermediates, molecular damage, and aging. Relation to melatonin. Ann. N. Y. Acad. Sci. 1998a, 854, 410-424.

Reiter, R. J., D. X. Tan \& W. Qi: A brief survey of observations and mechanisms related to suppression of oxygen toxicity by melatonin. Acta Pharmacol Sinica 1998b, 19, 575-581.

Reiter, R. J., D. X. Tan, C. Osuna \& E. Gitto: Actions of melatonin in the reduction of oxidative stress: a review. J. Biomed. Sci. 2000, 7, 444-458.

Richardson, J. S. \& Y. Zhou: Oxidative stress in the production and expression of neurotoxic $\exists$-amyloid. Rest. Neurol. Neurosci. 1996, 9, 207-211.

Schaufstatter, I. U., S. D. Revak \& C. G. Cochrane: Proteases and oxidants in experimental pulmonary inflammatory injury. J. Clin. Invest. 1984, 73, 1175-1184

Shibutai, S., M. Takeshita \& A. P. Grollman: Insertion of specific base during DNA synthesis past the oxidation-damage base 8oxodG. Nature 1991, 349, 431-434.

Shida, C. S., A. M. L. Castrucci \& M. T. Lamy-Freund: High melatonin solubility in aqueous medium. J. Pineal Res. 1994, 16, 198201.

Shigenaga, M. K., E. N. Aboujaoude, Q. Chen \& B. N. Ames: Assays of oxidative DNA damage biomarkers 8-oxo-2-deoxyguanosione and 8-oxoguanine in nuclear DNA and biological fluids by high-performance liquid chromatography with electrochemical detection. Meth. Enzymol. 1994, 234, 16-33.

Tan, D. X., L. D. Chen, B. Poeggeler, L. C. Manchester \& R. J. Reiter: Melatonin: A potent endogenous hydroxyl radical scavenger. Endocrine J. 1993a, 1, 57-60.

Tan, D. X., B. Poeggeler, R. J. Reiter, L. D. Chen, S. Chen, L. C. Manchester \& L. R. Barlow-Walden: The pineal hormone melatonin inhibits DNA-adduct formation induced by chemical carcinogen safrole in vivo. Cancer Lett. 1993b, 70, 65-71.

Tan, D. X., L. C. Manchester, R. J. Reiter, B. F. Plummer, J. Limson, S. T. Weintraub \& W. Qi: Melatonin directly scavenges hydrogen peroxide: a potentially new metabolic pathway of melatonins biotransformation. Free Radical Biol. Med. 2000, 29, $1177-1185$. 
Thomas, C. E. \& S. D. Aust: Free radicals and environmental toxins. Ann. Emerg. Med. 1986, 15, 1075-1083.

Troll, W. \& R. Wiesner: The role of oxygen radicals as a possible mechanism of tumor promotion. Ann. Rev. Pharmacol. Toxicol. 1985, 25, 509-528.

Tsou, T. C., C. L. Chem, T. Y. Liu \& J. L. Yang: Induction of 8- hydroxydeoxyguanosione in DNA by chromium (III) plus hydrogen peroxide and its prevention by scavengers. Carcinogenesis 1996, 17, 103-108.

Yoshikawa, T.: Free radicals and their scavengers in Parkinson's disease. Eur. Neurol. 1993, 33 (suppl 1), 60-68. 